\title{
RUANG PENYEMBUHAN UNTUK EFEK FISIK DARI KECANDUAN INTERNET
}

\author{
Clarin Sukri ${ }^{1)}$, J. M. Joko Priyono Santoso ${ }^{2)}$
}

1)Program Studi S1 Arsitektur, Fakultas Teknik, Universitas Tarumanagara, clarinsukri@gmail.com

2) Program Studi S1 Arsitektur, Fakultas Teknik, Universitas Tarumanagara, jokop@ft.untar.ac.id

\begin{abstract}
Abstrak
Keberadaan internet saat ini mengubah prilaku individu dalam banyak aspek yang tidak hanya memberi dampak positif tapi juga menimbulkan dampak negatif bagi para penggunanya. Maraknya penyalahgunaan internet yang terjadi menimbulkan sindrom-sindrom seperti kecanduan internet dan penyakit-penyakit yang menyerang fisik individu tersebut. Maka dari itu sebuah wadah untuk mengatasi efek fisik dari kecanduan internet pada remaja milenial ini menjadi perlu. Wadah yang juga memberi dukungan secara psikologi pada individu. Tapak berada di daerah dengan tumbuh kembang milenial terbanyak juga dengan pertimbangan pemanfaatan fungsi maka tapak terpilih adalah kawasan Semanan, Kalideres, Jakarta Barat. Metode perancangan yang digunakan adalah deskriptif kualitatif dan metode eksperimental dalam mendesain dimana dilakukan percobaan-percobaan dengan memasukkan aspek desain arsitektuk yang cocok dalam proyek dan analisis sintesis untuk mengetahui strategi desain arsitektur terbaik yang dapat mengoptimalkan program fasilitas ruang penyembuhan bagi para korban kecanduan internet. Dengan demikian rekomendasi desain yang dipilih adalah penerapan healing garden dan healing arsitektur pada rancangan "ruang penyembuhan untuk efek fisik dari kecanduan internet" yang akan dikaitkan dengan proses penyembuhan fisik tidak hanya guna penyembuhan bagi para pasien pecandu internet namun juga menjaga kenyamanan semua individu yang ada di dalamnya dari para perawat yang bekerja hingga para staff pengelola.
\end{abstract}

Kata kunci: arsitektur; milenial; penyembuhan

\begin{abstract}
The existence of the internet today changes individual behavior in many aspects that not only have a positive impact but also have a negative impact on its users. The rise of internet abuse that occurs causes syndromes such as internet addiction and diseases that attack the individual's physique. Therefore a container for dealing with the physical effects of internet addiction in millennial adolescents becomes necessary. Container which also provides psychological support to individuals. The site is in the area with the most millennial growth and also with consideration of function utilization, the chosen site is Semanan, Kalideres, West Jakarta. The design method used is descriptive qualitative and experimental methods in designing where experiments are conducted by incorporating aspects of suitable architectural design in the project and synthesis analysis to find out the best architectural design strategies that can optimize the program of healing room facilities for victims of internet addiction. Thus the design recommendations chosen were the application of healing gardens and architectural healing to the design of "healing rooms for the physical effects of internet addiction" which would be linked to the physical healing process not only for healing for internet addict patients but also maintaining the comfort of all individuals in in it from nurses who work to the management staff.
\end{abstract}

Keywords: architecture; healing; millenial 


\section{PENDAHULUAN}

Milenial yang lahir pada 1980an hingga 2000 berada di tengah-tengah pesatnya perkembangan teknologi. Dimana para milenial tumbuh dan berkembang dikelilingi oleh keakraban dengan komunikasi, media, dan teknologi digital, membuat mreka tidak mudah lepas dari teknologi ini. Milenial disini sebagai aspek yang sangat penting dalam perkembangan suatu daerah karna merupakan kelompok generasi terbesar dari usia produktif pada dunia perekonomian saat ini. Akses yang sangat mudah membuat penggunaan internet jadi tidak terkontrol, yang berefek menimbulkan sindrom-sindrom seperti kecanduan internet dan penyakit-penyakit yang menyerang fisik individu tersebut.

Kecanduan internet sendiri didefinisikan sebagai suatu perilaku penggunaan internet secara berlebihan dimana perilaku tersebut akan membuat individu hanya terfokus pada internet dan mengesampingkan rutinitasnya. Kecanduan internet berpotensi melumpuhkan aktifitas fisik yang berujung pada timbulnya penyakit-penyakit yang diakibatkan oleh menatap layar terlalu lama, tidak bergerak dari posisi karna terlalu fokus, dan mengesampingkan kebutuhan fisik seperti makan dan tidur. Penyakit yang umum terjadi diantaranya mabuk digital, computer vision syndrome, carpal tunnel syndrome, obesitas, maag, blepharitis, repetitive strain injuri, bahkan dapat menyababkan jantung dan epilepsi. Dengan penanganan yang berbeda-beda dari konsultasi dengan dokter untuk konsumsi obat hingga terapi fisiologi yang berupa elektroterapi, ultrasound, laser dan lain-lain.

Menerapkan healing arsitektur dan healing garden pada proses penyembuhan. Healing disini di maksud untuk mendukung proses penyembuhan secara medis dengan menggunakan aspek-aspek arsitektural seperti lansekap dan ruang diantara bangunan, interior yang meliputi penutup lantai, dinding, langit - langit, wallpaper, pencahayaan, desain pintu dan jendela, material bangunan, faktor manusia, yang meliputi panca indera (pendengaran, penciuman, penglihatan, peraba, dan pengecap).

Maka dari itu sebuah wadah untuk mengatasi efek fisik dari kecanduan internet pada remaja milenial ini menjadi perlu. Sebuah fasilitas dengan tujuan memulihkan kesehatan para remaja generasi milenial yang saat ini berada di puncak perekonomian, ditunjang dengan aktivitas-aktivitas yang dapat membangun kinerja para remaja agar terjauh dari kecanduan internet, dalam bentuk "Ruang Penyembuhan untuk Efek Fisik dari Kecanduan Internet" yang dirumuskan konsep perencanaan dan perancangannya melalui pendekatan gabungan antara Arsitektur Millenials dan Healing Arsitektur.

\section{KAJIAN LITERATUR}

Menurut Asmussen, arsitektur bertugas untuk membuat kita merasa nyaman seperti di rumah saat berada di lingkungan yang natural. la percaya bahwa dunia ini tidak hanya terdiri atas sesuatu yang tidak berarti, tapi lebih tepatnya dalam sebuah intrinsik spiritual atau material yang terhubung dengan mikroba terkecil dan bintang terjauh. Arsitektur bisa membantu orang untuk terhubung dengan kekuatan penyembuhan alam untuk menopang kehidupan mereka sehari-hari. Menggunakan bangunan yang mampu menciptakan keharmonisan dengan alam dan tempat. Hanya ketika jiwa tempat tersebut dikonkretkan dan dibuat nyata dalam bentuk bangunan yang sebenarnya, maka penyembuhan terbentuk (Coates, 2001). 
Healing adalah proses membangun kembali harmoni dalam diri individu dan merupakan hubungan timbal balik antara individu, keluarga, masyarakat, lingkungan, dan semangat hidup. Healing bukanlah proses mengobati, tetapi lebih kepada mengembalikan keseimbangan antara seluruh komponen tersebut. Jika tubuh sehat maka dapat diartikan bahwa terdapat keseimbangan, sebaliknya jika sakit maka tidak terdapat keseimbangan

Hosking dan Haggard mengemukakan komponen healing architecture antara lain lansekap (taman) dan ruang diantara bangunan, interior yang meliputi penutup lantai, dinding, langit - langit, wallpaper, cat, fabric, furnitur, noticeboards, pencahayaan, desain pintu dan jendela, material bangunan, seni dan dekorasi, faktor manusia, yang meliputi panca indera (pendengaran, penciuman, penglihatan, peraba, dan pengecap).

Warna diambil sebagai isu utama dalam perancangan karena warna merupakan bahasa jiwa yang mampu mempengaruhi suasana hati dan emosi kita. Warna memiliki dampak terhadap kesejahteraan manusia, dan dapat mengubah persepsi pandangan kita. Warna memiliki makna simbolik yang diakui oleh alam bawah sadar kita, yang mempengaruhi aliran dan jumlah energi dalam tubuh kita.

Hosking dan Haggard menyebutkan bahwa warna adalah interpretasi visual dari pigmen yang menyangkut semua material dan hanya dapat dilihat jika ada cahaya. Dengan demikian warna memiliki pengaruh pada volume, bentuk, ruang, dan perspektif.

Griffiths (2014) mencantumkan enam dimensi kecanduan internet, yaitu sebagai berikut :

a. Salience adalah menunjukkan dominasi aktivitas bermain permainan internet dalam pikiran dan tingkah laku.

b. Euphoria adalah mendapatkan kesenangan dalam aktivitas bermain permainan internet.

c. Conflict adalah pertentangan yang muncul antara orang yang kecanduan dengan orangorang yang ada disekitarnya (external conflict) dan juga dengan dirinya sendiri (internal conflict ) tentang tingkat dari tingkah laku yang berlebihan.

d. Tolerance adalah aktivitas bermain permainan internet mengalami peningkatan secara progresif selama rentang periode untuk mendapatkan efek kepuasan.

e. Withdrawal adalah perasaan tidak menyenangkan ketika tidak melakukan aktivitas bermain permainan internet.

f. Relapse and Reinstatement adalah kecenderungan untuk melakukan pengulangan terhadap pola-pola awal tingkah laku kecanduan atau bahkan lebih parah walaupun setelah bertahun-tahun hilang dan dikontrol.

Orzack (2004) menggolongkan gejala-gejala yang nampak pada individu yang mengalami kecanduan internet menjadi dua golongan, yaitu : [4]

a. Gejala-gejala psikologis, yaitu mengalami euphoria saat menggunakan komputer, tidak mampu menghentikan aktivitasnya, membutuhkan waktu tambahan dalam menggunakan komputer, berbohong kepada keluarga dan rekan kerja mengenai aktivitasnya dan mendapat masalah dengan sekolah atau pekerjaannya.

b. Gejala-gejala fisik, yaitu mengalami carpal tunnel syndrome, mata menjadi kering, migren atau sakit kepala, sakit punggung, gangguan pada pola makan, mengabaikan kesehatan dan gangguan tidur.

Sedangkan menurut Nicholas Yee (2002) menyebutkan indikator dari individu yang mengalami kecanduan terhadap permainan internet, memiliki gejala, antara lain:

- Cemas, frustasi dan marah ketika tidak melakukan permainan.

- Perasaan bersalah ketika bermain.

- Terus bermain meskipun sudah tidak menikmati lagi. 
- Teman atau keluarga mulai berpendapat ada yang tidak beres dengan individu.

- Masalah dalam kehidupan sosial.

- Masalah dalam hal finansial atau hubungan dengan orang lain.

Dampak terhadap Kepribadian

a. Suka mencuri.

Banyak kasus yang terjadi dimana seseorang mencuri demi mendapakan komputer yang diinginkan.

b. Malas.

Akibat kecanduan bermain permainan internet, seseorang menjadi sering lupa dengan kewajibannya.

c. Suka bolos sekolah.

Sering seseorang atau anak bolos sekolah dan pergi ke tempat permainan internet bersama teman-temannya.

d. Suka berbohong.

Sikap seseorang yang suka berbohong biasanya terkait dengan kegemarannya bermain permainan internet.

e. Kurang bergaul.

Seseorang akan menjadi jarang bergaul karena hubungan dengan teman dan keluarga menjadi renggang akibat waktu bersama mereka yang jauh berkurang.

f. Menjadi agresif.

Kekerasan dalam permainan internet menimbulkan perilaku agresif pada anak-anak dan remaja.

Faktor-Faktor Penyebab Perilaku Kecanduan Permainan Internet :

a. Kurang perhatian dari orang-orang terdekat.

b. Strees atau depresi.

c. Kurang kontrol.

d. Kurang kegiatan.

e. Lingkungan.

f. Pola asuh.

Menurut Rini (2011: 28) terdapat empat dampak permainan internet yakni terhadap kesehatan, kepribadian, pendidikan, keluarga dan masyarakat. Dampak dampak tersebut antara lain: Dampak terhadap Kesehatan :

a. Saraf mata dan otak, serta kesehatan jantung akan menurun.

b. Berat badan menurun akibat lupa makan dan minum karena keasyikan bermain permainan internet.

c. Karena banyak duduk dalam waktu yang lama, lambung dan ginjal bisa rusak.

d. ngemil, kemungkinan besar badan akan meningkat.

e. Stress.

f. RSI Repetitive strain injury adalah istilah untuk menyebutkan cendera fisik berulang-ulang dan dapat menyebabkan kecacatan, misalnya pegal dan nyeri tulang belakang yang bisa membuat bentuk tulang belakang tidak proposional.

g. Kerusakan mata.

h. Maag. umumnya banyak yang lupa waktu termasuk lupa jam makan.

i. Epilepsi (ayan). Beberapa penelitian melaporkan bahwa kilatan-kilatan cahaya dengan pola tertentu pada permainan internet dapat memicu penyakit epilepsi. 


\section{Healing Fisik}

\section{Repetitive Strain Injury (RSI)}

- cidera persendian nyeri, kesemutan, bengkak, out of control

. duduk terlalu lama tidak bergerak

Penanganan

- hetikan aktifitas, kompres berkala, analgesics(obat), biofeedback(device), terapi fisik, ultrasound terapi (device), fisioterapi

\section{Epilepsi / ayan}

- impuls listrik berlebih pada otak kejang - kejang

. menatap layar terlalu lama

Penanganan

- pengaturan pola makan, obat pencegah kejang, akupuntur, yoga, vitamin, psikoterapi

\section{Mabuk digital}

- sangat pusing, mual, sakit kepala, tegang pada mata, celeng (pengelihatan terasa berguncang).

. penggunaan komputer yang terlalu lama

\section{Penanganan}

\section{Blepharitis}

- Pengaturan waktu bermain dan istirahat

- mata merah, gatal, bengkak

. menurunnya frekuensi kedipan mata

Penanganan

- obat tetes mata, mengistirahatkan mata secara berkala

\section{Computer Vision syndrome}

- sakit kepala, penglihatan kabur dan ganda, cedera mata, nyeri pada area leher-kepala, sensitif terhadap cahaya, ketidakmampuan melihat fokus pada benda jarak jauh

Penanganan

- obat tetes mata, mengistirahatkan mata secara berkala

\section{Carpal Tunnel Syndrome}

- mati rasa, kesemutan, rasa terbakar, nyeri, sensasi kejut tiba-tiba, out of control

\section{Penanganan}

- pemakaian Wrist brace, obat pereda sakit, pengaturan aktifitas, latihan gerak,

\section{Obesitas}

- penaikan berat badan drastis

. pola makan dan tidur tidak teratur

Penanganan

- pengaturan pola makan, obat (jika perlu) dan olah raga

\section{Maag}

- radang lambung

nyeri uluhati, muntah, berat badan turun .stress, pola tidur, pola makan

Penanganan

- pengaturan pola makan, pemberian obat, meditasi, relaksasi, psikoterapi

\section{Jantung}

- pengerasan pembuluh arteri

.kurang aktivitas fisik, pola makan

Penanganan

- pengaturan pola makan, pemberian obat dan olah raga

Saraf mata dan otak

Penanganan

- pengaturan pola makan, pemberian obat 


\section{Contoh penanganan}

\section{LASER}

SACRALGIA (NYERI SACRUM)

$\begin{array}{ll}\text { Lo812 } & \text { Program: } \\ \text { program: Lo812 sacralgia }\end{array}$

\begin{tabular}{|c|c|}
\hline \multicolumn{2}{|l|}{$\overline{\text { Parameter terapi" }}$} \\
\hline dosis: & $16 \mathrm{~J} / \mathrm{cm} 2$ \\
\hline dave: & melatui probe \\
\hline area iradiasic & $1 \mathrm{~cm} 2$ \\
\hline frekuensí & $10 \mathrm{~Hz}$ \\
\hline duty tactor (DF): & $80 \%$ \\
\hline Asesoris yang disarankan: & probe laser inframerah \\
\hline Frekuensi perawatan: & $3 \times$ per minggu \\
\hline Jumlah perawatan: & 12 atau sampai nyeri mereda \\
\hline Efek: & analgesilk vasodilatasis mporetaxation \\
\hline
\end{tabular}

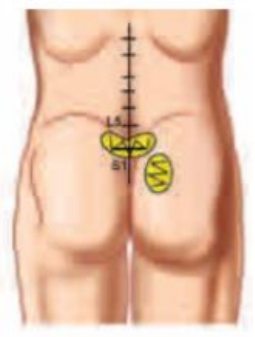

\section{ELEKTROTERAPI}

\begin{tabular}{|c|c|}
\hline $\begin{array}{l}\text { MYALGIA } \\
\text { Program: }\end{array}$ & E-1663 \\
\hline \multicolumn{2}{|l|}{ Parrameter terapi: } \\
\hline arus & TENS \\
\hline jenis & simetris \\
\hline pulse: & 100us \\
\hline trekuensi pulse: & $100 \mathrm{~Hz}$ \\
\hline$\overline{\text { modulasi }}$ & trapezoidal surges \\
\hline Posisi elektroda: & elektroda $4 \times 6 \mathrm{~cm}$ di atas otot target \\
\hline Lama perawatan: & 10.20 menit, step 1 menit \\
\hline Frekuensi perawatar: & dua hari sekall \\
\hline Jumlah perawatar: & 8 \\
\hline intensitas: & sampai tingkat motor threshold \\
\hline Etok: & analgesik vasodiliatasi \\
\hline
\end{tabular}

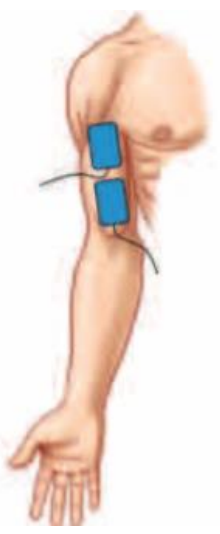

ULTRASOUND

ARTHRITIS RHEUMATOIDES (REMATIK) - SUBAQUALIS Program: $\quad$ U0002 arthritis theumatoides (rentatik)- subaqualits W-0002 arthritis theumatoides (rematik)- subaqualis

Frekuensi pembawa: $1 \mathrm{MHz}$

\begin{tabular}{ll}
1 MHtz \\
\hline duty factor (DF) & 1.2 (50:5) \\
\hline
\end{tabular}

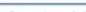

\begin{tabular}{ll}
\hline Aplikator yang disarankan: & kepala ultrasound, $4 \mathrm{~cm}^{2}$ \\
\hline Lama aplikasi: & 5 menit
\end{tabular}

Lama aplikasi: 5 mene

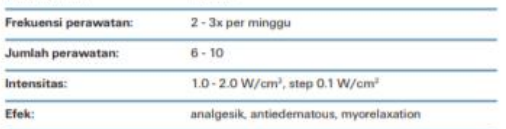

Intensitas:

$20 \mathrm{~W} / \mathrm{cm}^{3}$, step $0.1 \mathrm{~W} / \mathrm{cm}^{3}$

Catatar: Aplikasi Subaqual. Jarak kepata ultrasound dari area arget $10-12 \mathrm{~cm}$.
Suhu air: $36^{\circ} \mathrm{C}$.
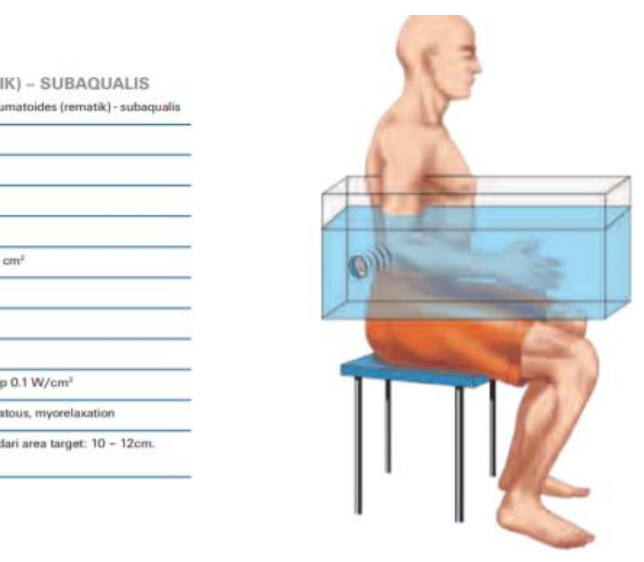

SPASM (KEJANG)

\begin{tabular}{|c|c|}
\hline Program: & M.0054 \\
\hline \multicolumn{2}{|l|}{ Parameter terapi: } \\
\hline arus: & serangkaian magnetic pulse \\
\hline intensitas medan magnet: & $120 \mathrm{mt} / 10$ \\
\hline bentuk pulse: & rectangular pulse (panjang) \\
\hline Aplikator yang disarankan: & solenoid $30 \mathrm{~cm}$, solenoid $60 \mathrm{~cm}$, double disk \\
\hline Lama perawatan: & 30 menit \\
\hline Frekuensi perawatan: & setiap hari \\
\hline Jumlah perawatan: & $\begin{array}{l}\text { perawatan janpka panjang 10-14 minggu - sesuai dengar } \\
\text { berkurangmya myeri }\end{array}$ \\
\hline Posisi aplikator: & $\begin{array}{l}\text { solenoid } 30 \mathrm{~cm}, 60 \mathrm{~cm} \text {, double diak - untuk kejang lokal } \\
\text { pada ofot tungkai, di area nyeri }\end{array}$ \\
\hline
\end{tabular}

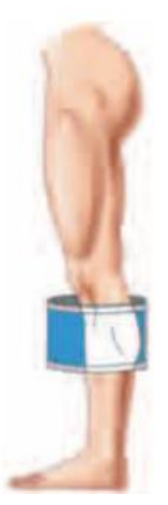

Gambar 1. Penanganan Fisioterapi Sumber: Brosur BTL 5818 SLM, 2019 


\section{METODE}

Metode penelitian yang digunakan adalah metode deskriptif kualitatif, yaitu mengambarkan fenomena aktual yang ditemukan pada saat pengumpulan data dan menganalisanya, setelah itu mengevaluasi hasil temuan untuk mendapatkan data deskriptif. Dengan teknik pengumpulan data berupa metode observasi yang di lakukan dengan pengamatan dan pencatatan data secara sistematis terhadap fenomena yang diselidiki yaitu survey lapangan. Lalu metode dokumentasi dengan memanfaatkan dokumen tertulis berupa buku, artikel, jurnal, skripsi, dan sebagainya.

Penggunaan metode analisis sintesis, dengan di lakukannya pendekatan-pendekatan yang merupakan suatu tahapan kegiatan yang terdiri dari rangkaian telaah pada kawasan. Proses analisis dibagi dua yaitu makro yang merupakan analisis skala kawasan, analisis tapak dan analisis mikro yang merupakan analisis terhadap objek perencanaan, meliputi analisis pelaku, analisis aktifitas, analisis ruang, analisis view, analisis bangunan, analisis elemen fisik serta struktur juga utilitas. Data yang diperoleh kemudian dianalisis melalui pendekatan programatik perancangan yaitu menggunakan teori-teori perancangan arsitektur yang berkaitan degan perancangan ruang penyembuhan untuk efek fisik dari kecanduan internet.

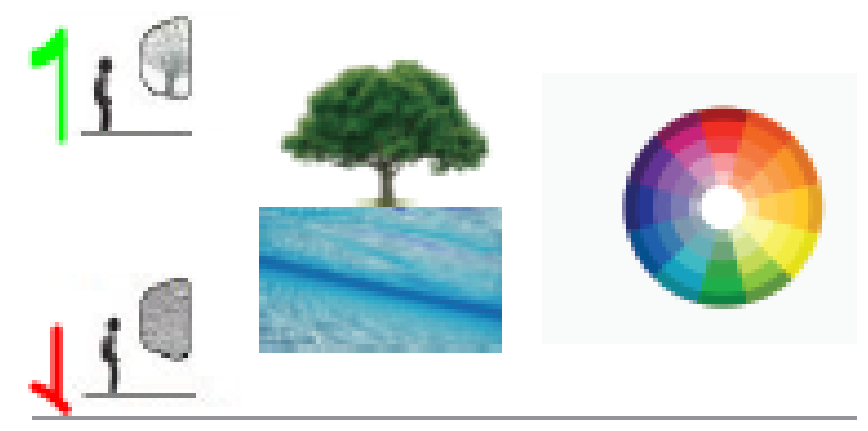

Gambar 2. Indra penglihatan

Sumber: Penulis, 2019

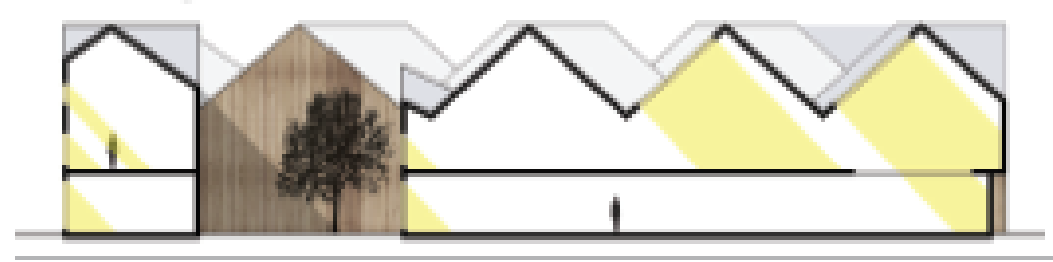

Gambar 3. Pencahayaan Alami

Sumber: healingthrougharchitecture , 2019

Pendekatan lain yang digunakan adalah metode eksperimental dengan menggunakan percobaan-percobaan dari teori healing architecture guna mendapatkan desain terbaik dalam rancangan. Healing architecture adalah sebuah konsep desain dimana arsitektur turut serta dalam proses penyembuhan pengguna. Pendekatan ini sering digunakan pada perancangan fasilitas kesehatan. Komponen healing architecture antara lain lansekap dan ruang diantara bangunan, interior yang meliputi penutup lantai, dinding, langit - langit, wallpaper, pencahayaan, desain pintu dan jendela, material bangunan, faktor manusia, meliputi panca indera (pendengaran, penciuman, penglihatan, peraba, dan pengecap).

Metode Therapeutic community digunakan dalam proses penyembuhan. Metode penyembuhan tersebut dapat diterapkan melalui konsep therapeutic spaces. Therapeutic spaces dapat dideskripsikan sebagai lingkungan terbangun yang berpusat pada manusia, disiplin evidence-based, yang bertujuan untuk mengidentifikasi dan mendukung elemen spasial yang berinteraksi dengan fisiologi dan psikologi manusia. 
Untuk menentukan konsep pada rancangan, digunakan Metode Pemrograman oleh Donna P. Duerk. Proses perancangan berangkat dari isu yang digunakan untuk mencari informasi terkait hal-hal yang sudah ada (existing state) dan untuk menciptakan tujuan (goals), kriteria rancang (performance requirements), dan konsep yang dikembangkan untuk mencapai wujud yang diinginkan (future state).

Kriteria desain objek rancang diambil dari metode penyembuhan yang diterapkan pada rancangan, poin-poin tersebut adalah:

1) Care in the community (Rancangan harus dapat mendorong dan mengakomodasi terjadinya interaksi dan sosialisasi).

2) Design for domesticity (Rancangan harus dapat menciptakan dan memberi suasana seperti di rumah).

3) Social valorisation (Rancangan harus dapat menjaga privasi dan keamanan pengguna).

4) Integrated with nature (Rancangan harus dapat memanfaatkan dan memaksimalkan elemen-elemen alami di tapak dan sekitarnya).

\section{DISKUSI DAN HASIL}

Proses healing yang akan dipercepat dengan bantuan desain bangunan arsitektural dan lansekap berupa healing garden. Tujuan dari semua lingkungan penyembuhan adalah untuk melibatkan pasien dalam proses penyembuhan dan pemulihan diri. Sebagai hasilnya, ruangruang ini dirancang untuk memelihara dan terapi untuk mengurangi stres pasien dan keluarga. Untuk mempromosikan pemulihan, arsitektur penyembuhan bertujuan untuk:

a. Menghilangkan aspek stress lingkungan, seperti kebisingan, kurangnya privasi, kualitas udara yang buruk dan cahaya yang menyilaukan.

b. Menghubungkan pasien dan alam dengan memberikan pemandangan luar ruangan dan fitur alami lainnya, termasuk taman dan elemen air.

c. Meningkatkan rasa kendali pasien dengan menawarkan opsi dan pilihan seperti pada pencahayaan dan cakupan view.

d. Mendorong peluang untuk dukungan sosial, seperti menyediakan tempat duduk yang sesuai di kamar pasien dan privasi untuk kelompok kecil.

e. Berikan aktifitas positif, seperti seni interaktif, perapian, akuarium, koneksi internet, musik, atau instalasi video atau cahaya yang cocok dengan pengaturan perawatan kesehatan.

f. Menginspirasi perasaan damai, harapan, refleksi dan koneksi spiritual

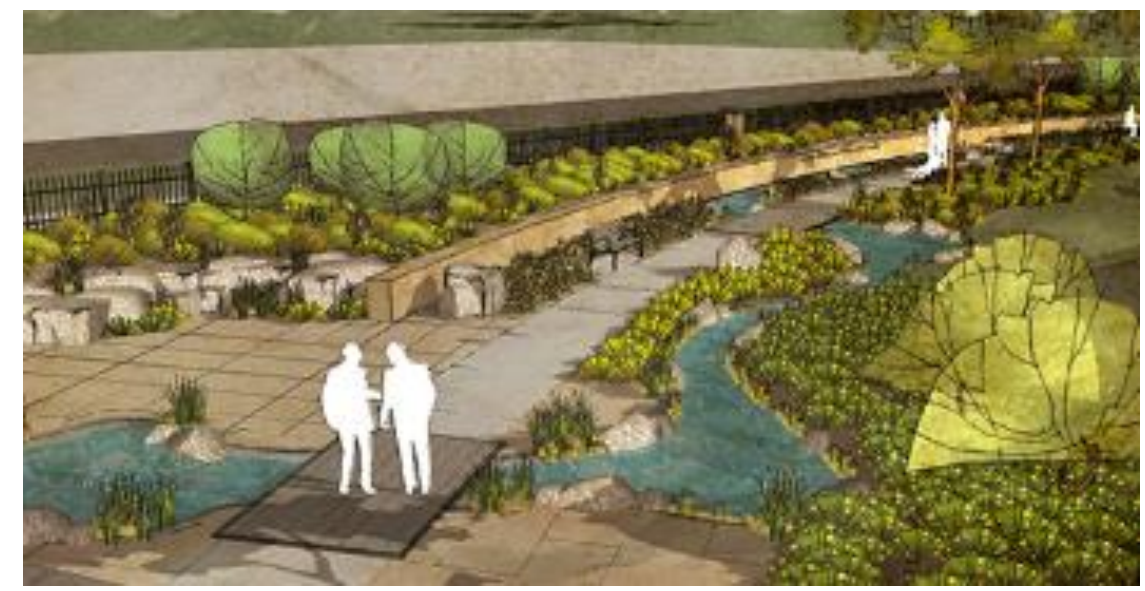

Gambar 4. Healing garden

Sumber: confluencelanscape, 2019 


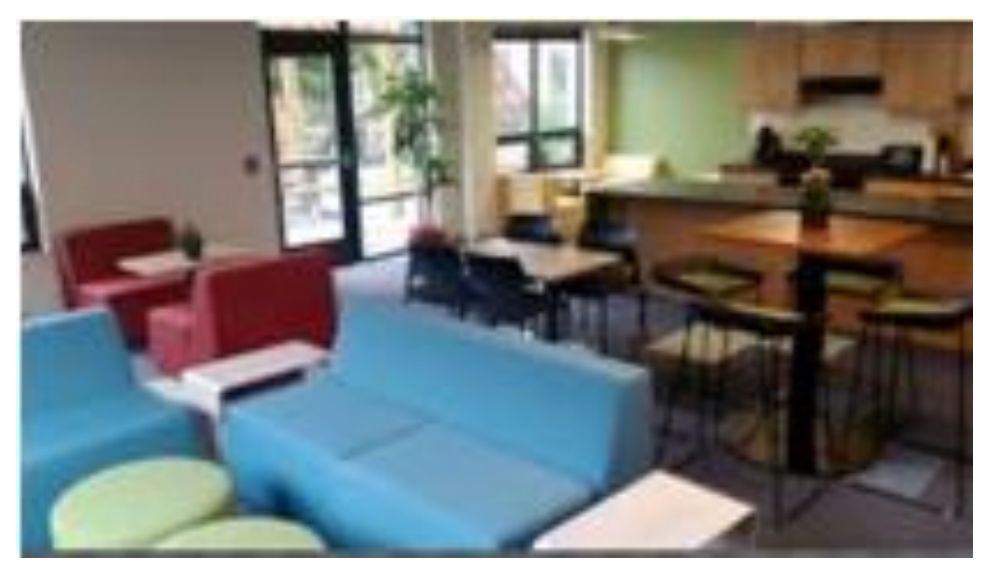

Gambar 5. Workcafe

Sumber: downstreet.org, 2019

Kawasan

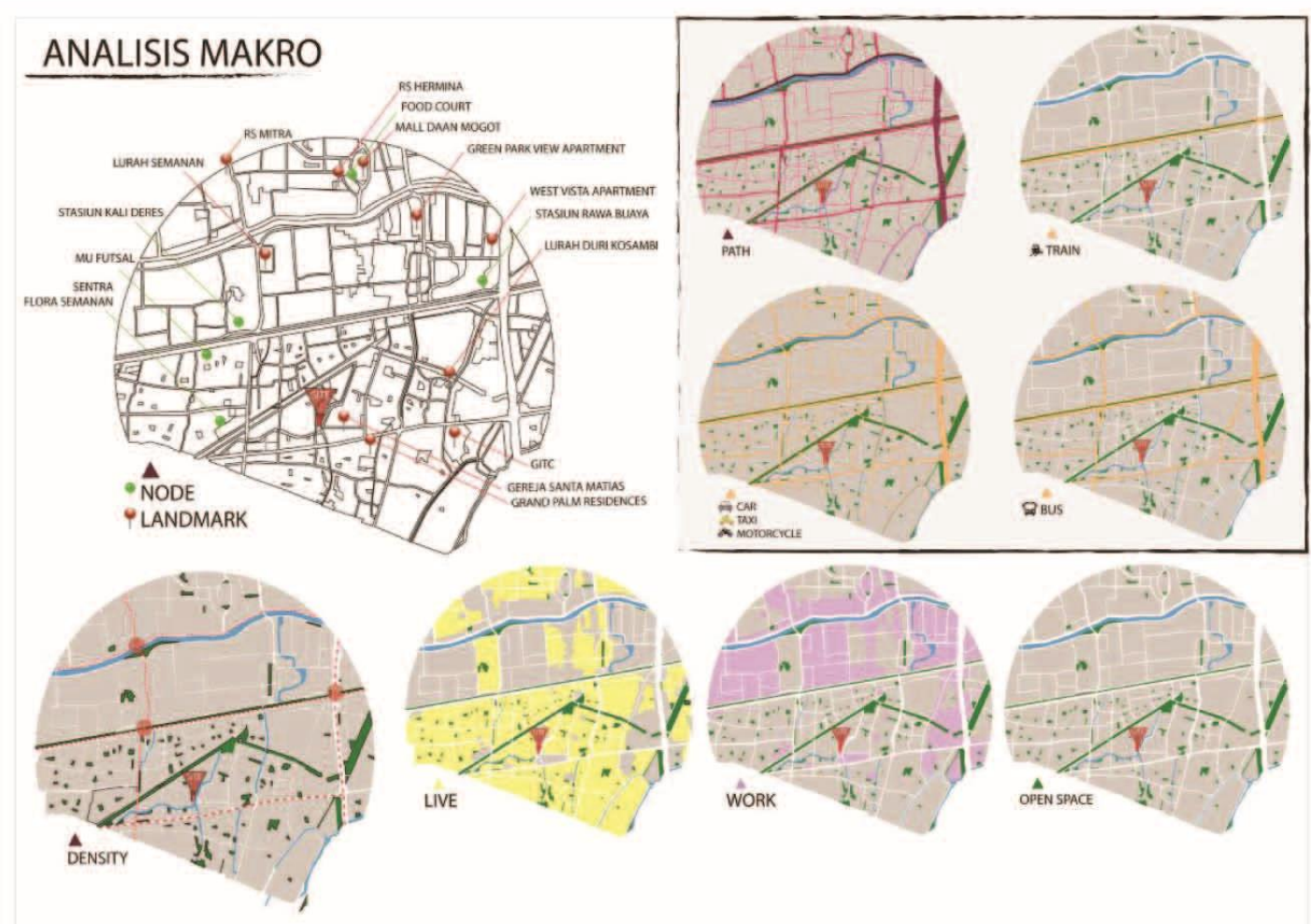

Gambar 6. Analisis Makro Kawasan Sumber: Penulis, 2019

Berada di kawasan Semanan, Kalideres, Jakarta Barat. Kawasan terpilih karna menjadi kawasan dengan milenial terbanyak diJakarta. Dengan mapping yang dilakukan di atas mengenai node, landmark, kepadatan, zonasi, sirkulasi dan akses. Dapat dilihat tapak berada di daerah yang cukup strategis dan mudah di jangkau. 

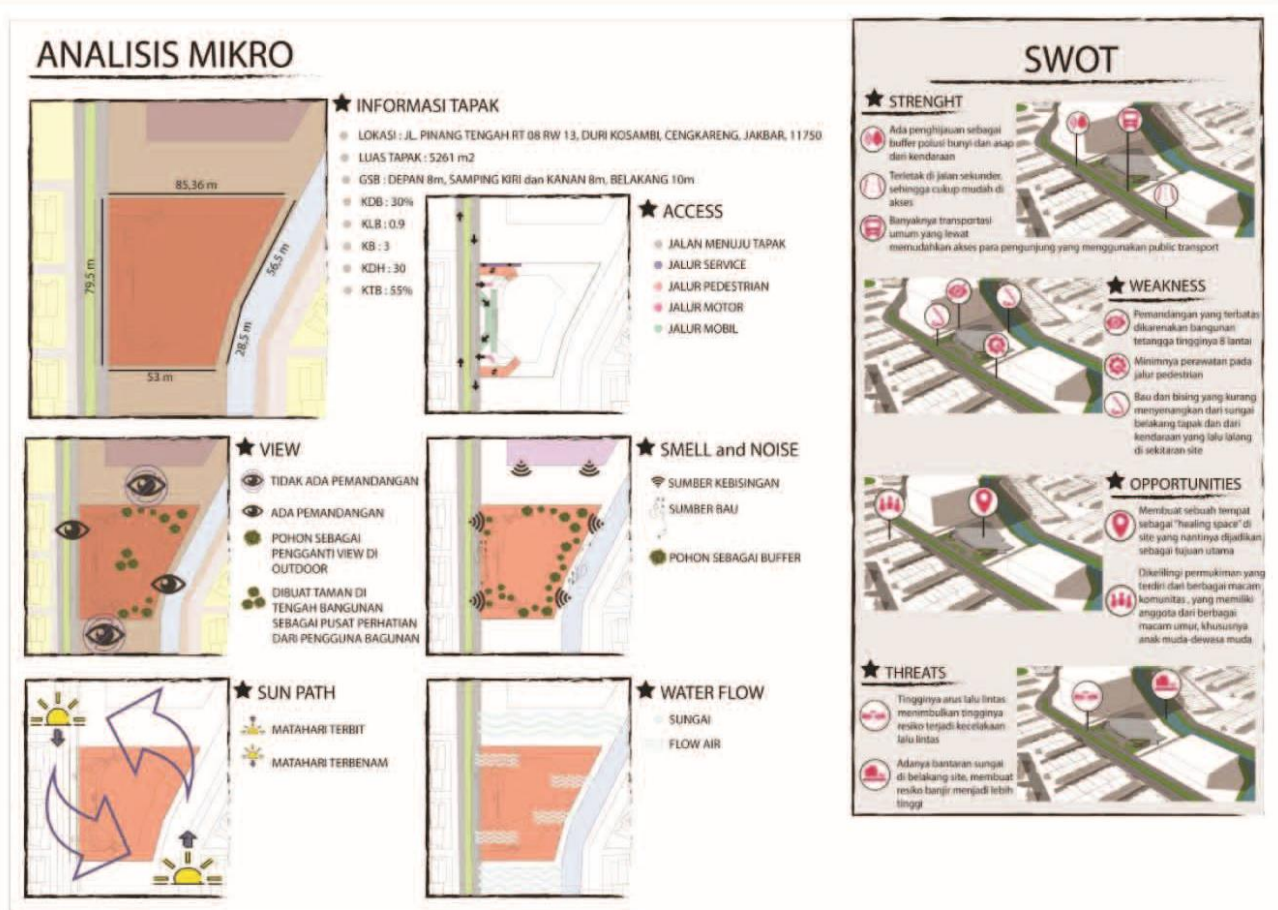

Gambar 7. Analisis Mikro Kawasan

Sumber: Penulis, 2019

Lalu dari data SWOT dan analisis mikro yang dilakukan pada tapak meliputi view, bising, akses dan lainnya dapat dilihat bahwa tapak memiliki kelebihan yang mendukung berdirinya sebuah helaing space dengan ruang hijau yang memadai, arah matahari yang tidak tertutup bangunan lain, akses jalan yang cukup mudah (tidak membingungkan), meski ketinggian bangunan dengan tetangga cukup jauh pada satu sisi namun dapat di atasi dengan menjadikannya dasar membentuk massing bangunan yang berundak dan tinggi pada sisi tersebut.

Maka dari itu program yang di usulkan adalah

a. Prevent

Upaya pencegahan dalam bentuk Edukasi, yang memberi arahan edukasi mengenai bahaya nya kecanduan internet, efek-efek sampinya, gejalanya, pencegahannya, dalam bentuk program wisata sehingga pengunjung dapat datang untuk menikmati aktifitas yang disediakan sekaligus belajar. Dalam bentuk ruang kelas, galeri, workshop lukis dan workshop musik yang tidak hanya jadi pengalih dari kecanduan internet tapi juga jadi sarana penyembuhan dengan aspek melihat warna dan mendengar irama (juga dapat menjadi aspek pendukung untuk pengunjung lain). Dilengkapi dengan area gym untuk mengoptimalkan aktifitas fisik para pasien yang cenderung kurang ber olah raga.

b. Healing

Menyediakan fasilitas penyembuhan bagi mereka korban kecanduan internet dalam bentuk terapi-terapi fisik, konsultasi dengan para ahli, aktifitas-aktifitas fisik, dan sosialisasi dengan komunitas. Untuk penanganan pasien dari terapi fisik akibat dari penyakit RSI, CTS, CVS, dan epilepsi di lakukan fisioterapi yaitu terapi manual, ultrasound terapi, dan terapi-terapi lain dengan bantuan alat. Lalu pengobatan dalam bentuk konsultasi akibat dari mabuk digital, obesitas, maag, jantung, saraf akan mendapat sesi konsultasi untuk pengaturan pola makan dan konsumsi obat secara rutin. Dalam bentuk ruang-ruang penanganan sesuai pengelompokan penyakit dengan penanganan yang serupa misalnya ruang konsiltasi yang dilaksanankan individual dalam ruang, lalu ada ruang terapi yang memanfaatkan indra 
pencahayaan matahari untuk pencahayaan alami yang mendukung proses healing juga dengan koneksi langsung dengan ruang luar terbuka berupa healing garden dengan aspek pepohonan dan air yang juga menjadi bagian dari terapi healing tersebut.

c. Protect

Upaya dukungan bagi para pecandu internet dalam bentuk komunitas. Komunitas bagi mreka yang mau ikut serta dalam membantu pasien yang butuh penanganan mengenai kecanduan internet. Komunitas atas dasar kepedulian akan masa depan para remajaremaja pecandu internet ini membuka kesempatan untuk mreka menciptakan programprogram yang dapat membantu kesembuhan berupa ke ikut sertaan dalam workshop lukis dan musik. Disediakan pula café yang menjadi ruang komunal tidak hanya memenuhi kebutuhan pokok sebagai tempat makan namun juga jadi tempat berkumpul yang di desain terbuka dan punya akses langsung dari entrance pedestrian untuk memperkuat sifat public dari ruang komunal ini.

\section{KESIMPULAN DAN SARAN}

Kesimpulan

Sebuah fasilitas dengan tujuan memulihkan kesehatan fisik generasi milenial, dalam bentuk "Ruang Penyembuhan untuk Efek Fisik dari Kecanduan Internet" yang dirumuskan dengan konsep pendekatan Healing Arsitektur ini menjadi cara yang efektif untuk meningkatkan proses penyembuhan bagi para pasien. Healing garden juga bisa digunakan untuk ruang tunggu menciptakan keadaan yang nyaman bagi tidak hanya pasien namun pengunjung lain yang ada dalam bangunan. Sirkulasi menjadi sangat penting dalam ruang penyembuhan karna jalan yang berbelit dan memusingkan akan menjadi poin minus dalam mendesain. Pengelompokan zoning ruang private dan public yang harus di batasi dengan jelas agar tidak mengganggu proses healing. Interior garden yang juga dapat mendukung proses healing menjadi aspek yang perlu di perhatikan maintenance nya menjaga agar taman tetap dapat hidup dengan bukaan namun jangan sampai mengganggu pengunjung. Banyak nya ruang terbuka harus diimbangi dengan AC karna kondisi cuaca di Jakarta yang panas. Bukaan yang guna memasukkan cahaya ke bangunan juga harus di imbangi dengan shading dan buffer agar panas juga tidak ikut masuk.

\section{Saran}

Penerapan arsitektur yang masih bisa di kembangkan, tidak hanya dengan sebuah ruang diberi aspek yang mendukung healing namun bentukan dari ruang itu sendiri merupakan bagian dari proses healing. Studi lebih dalam mengenai penyakit, gejala, dan penanganannya untuk menemukan bentukan ruang terbaik yang mendukung proses healing. Pemanfaatan sustainable energi juga bisa menjadi pertimbangan sehingga tidak hanya ramah bagi pengunjung tapi juga bagi lingkungan. Perlunya studi solar chart sebagai dasar mendesain karna matahari merupakan aspek penting dalam proses healing ini. Melihat banyak nya kaum milenial dengan gejala fisik nya di jakarta maka diharapkan pembangunan lanjutan dan menyebar dari proyek serupa. Masih mungkin dimasukkan nya aspek-aspek wisata edukasi lain yang mendidik para remaja milenial mengenai cara guna internet yang baik di sisi lain juga dapat sebagai daya tarik pengunjung untuk datang ke proyek ruang penyembuhan untuk efek fisik dari kecanduan internet ini. 


\section{REFERENSI}

Aqila, S. (2010). Cara Cerdas Mengatasi Anak Kecanduan Game. Jogjakarta: A plus books. Bandani, M. (1984). Typology as a Form Convention. AA Files no. 6

Beggs, J. L. (2015). Healing through Architecture. Thesis, University of Waterloo.

Griffiths MD, King DL, Demetrovics Z. DSM-5 internet gaming disorder needs a unified approach to assessment. Neuropsychiatry. 2014

Hosking, S. H. L. (1999). Healing the Hospital Environment: Design, Management, and Maintenance of Healing the Hospital Environment. New York, E \& FN Spon.

Lathouri, M. (2011). The city as a Project. Dalam C. Lee, \& S. Jacoby, Typological Urbanism. London: Wiley.

Orzack, M. H. "The Simptom of Computer Addiction", 1999. http://www.computeraddiction.com,

Rini, A. (2011). Menanggulangi Kecanduan Game On-Line Pada Anak. Jakarta. Pustaka Mina Young, K. S. (1996). Internet Addiction: The Emergence of a New Clinical Dosirder. Cyber

Psychology and behavior vol 1

https://www.mayoclinic.org/diseases-conditions/personality-disorders/diagnosistreatment/drc-20354468

https://psikologihore.com/gangguan-kepribadian/ https://www.ncbi.nlm.nih.gov/pmc/articles/PMC3480687/

https://www.researchgate.net/publication/328259398_Tingkat_Kecanduan_Internet_pada_R emaja_Aal 